\title{
A construção da narrativa em Primeiras Estórias
}

\author{
Benedito Veiga ${ }^{1}$ \\ Comprei uns óculos novos \\ óculos dos mais excelentes, \\ não tem aros, não tem asas, \\ não tem grau e não tem lentes... \\ João Guimarães Rosa \\ Tutaméia
}

De saída, o encaminhamento é sobre a denominação do livro Primeiras Estórias: por que “estórias"? Por que "primeiras"? Essas indagações tornaram-se continuadas para a recepção crítica dessa produção roseana, desde seu lançamento, como registra, por exemplo, Paulo Rónai em "Vastos Espaços", ensaio integrante da quarta edição do livro:

$\mathrm{Na}$ falta de precisão na "orelha" do volume, o título pede duas palavras de explicação. O epíteto não alude a trabalhos da mocidade ou anteriores aos já publicados em volumes, e sim à novidade do gênero adotado, a estória. Esse neologismo de sabor popular, adotado por número crescente de ficcionistas e críticos, embora ainda não registrado pelos dicionaristas, destina-se a absorver um dos significados de "história", o de "conto" (= short story). A oposição conceitual resulta nitidamente deste trecho de "Nenhum, Nenhuma": "Era uma velha, uma velhinha - de história, de estória - velhíssima, a inacreditável". (ROSA, 1968, p.7)

Rónai, além de apontar significados de "estória" próximos ao de ficção, direciona caminhos para a compreensão da obra dentro da própria obra, qual seja: Primeiras Estórias dentro de Primeiras Estórias ou Guimarães Rosa dentro de Guimarães Rosa, reconhecendo, portanto, o jogo constante de metalinguagem e intertextualidade, indissociáveis das propostas literárias roseanas.

Eduardo Portella também investe na temática, no artigo "A Estória cont(r)a a História", divulgado no Jornal do Brasil-RJ, de 30 de dezembro de 1967. Para esse estudioso, é inútil aproximar-se da obra de JGR em busca de correspondências lineares, à procura de manifestações declaradamente ideológicas: “(JGR) não pretende ser um ideólogo, mas simplesmente escritor comprometido com a invenção: "tudo se finge, primeiro; germina autêntico é depois. Um escrito, será que basta?’” (PORTELLA, 1991, p.198)

\footnotetext{
1 Professor titular aposentado da Universidade Estadual de Feira de Santana. E-mail: veigabenedito@gmail.com
} 
Portella prossegue com Rónai e acrescenta, em JGR, o cuidado no confronto real versus irreal, passando pela discussão entre o histórico e o ficcional, para se chegar até a melhor compreensão de "estória", como está expresso em "Aletria e Hermenêutica", o primeiro prefácio de Tutaméia: “A estória não quer ser história. A estória, a rigor, deve ser contra a História. A estória, às vezes, quer-se parecida à anedota"(ROSA, 1968, p.2).

Aurélio Buarque de Holanda Ferreira, em seu dicionário Novo Aurélio - Século XXI, faz duas advertências importantes: quanto ao sentido de "anedota", registrado como um "(...) relato sucinto de um fato jocoso ou curioso", e quanto ao sentido de "estória", apresentado sob a chamada, “(...) recomenda-se apenas a grafia história, tanto no sentido de ciência histórica, quanto no de narrativa de ficção, conto popular, e demais acepções".

Aparentemente, mas contrário ao senso da proposta roseana - "a história não quer ser história" - estaria resolvida a questão. JGR, no entanto, insiste em sua explicação na proximidade de sentido entre analogia e estória, como está registrado em Tutaméia:

A anedota, pela etimologia e para a finalidade, requer fechado ineditismo. Uma
anedota é como um fósforo: riscado, deflagrada, foi-se a serventia. Mas sirva
talvez ainda a outro emprego a já usada, qual mão de indução ou, por exemplo,
instrumento de análise, nos tratos da poesia e da transcendência. Não será sem
razão que a palavra "graça" guarde os sentidos de gracejo, de dom sobrenatural,
e de atrativo. E que, na prática de arte, comicidade e humorismo atuem como
catalisadores ou sensibilizadores ao alegórico espiritual e ao não-prosaico, é
verdade que se confere de modo grande. Risada e meia? Acerte-se nisso em
Chaplin e Cervantes. Não é o chiste rasa coisa ordinária; propondo-nos realidade
superior e dimensões para mágicos novos sistemas de pensamento. (ROSA,
1968, p.3)

As noções de anedota e estória intertextualizam-se, com o recurso às ambiguidades de sentido, surgidas a partir do termo "graça”, tomado como exemplo: "gracejo", "dom sobrenatural”, "atrativo". JGR atenta para os aspectos da "comicidade" e do "humorismo" como recursos para escapar do trivial e do prosaico linguísticos, citando, como analogias, as produções de Chaplin e Cervantes: o chiste propõe uma “(..) realidade superior e dimensões para mágicos novos sistemas de pensamento".

Nesse embate significativo, Eduardo Portella, no texto já citado, afirma que a invenção de JGR não é um devaneio, um capricho ou um luxo desnecessário. E remete a Tutaméia, pelo viés de "Hipotrélico", o segundo prefácio desse livro: "Sob mais que, tratando-se de palavra inventada, e, como adiante se verá, embirrando o hipotrélico em não tolerar neologismos, começa ele por negar nominalmente a própria existência” (ROSA,1968, p.64).

Portella nega, em JGR, a literatura como cópia ou reprodução da natureza. A estória não é nem espelho da natureza nem segunda natureza: "Se nos fosse lícito, afirmaríamos ser ela a terceira 
natureza. Através da mimese, a arte faz emergir até a plenitude, até o esgotamento, até a purificação, tudo o que a natureza, a realidade ou seu dinamismo, se mostram incapazes de objetivar numa obra” (PORTELLA,1991, p.200)

Com a possível restauração da mimese aristotélica, entende-se que a linguagem não está fora do homem como uma simples ferramenta: a estória não é apenas a realidade projetada, mas a própria constituição da realidade. E, apenas sendo contra a história, a estória consegue contar a história.

No que toca à questão - por que "primeiras"? -, a consulta à produção roseana mais uma vez se impõe. As Primeiras Estórias são lançadas em agosto de 1962; Tutaméia: Terceiras Estórias, em julho de 1967. Aonde se encontrariam as "segundas estórias"?

O ideário das estórias encobre hipóteses sobre a gênese da produção do escritor. Umadelas sustenta que as Primeiras Estórias seriam o legitimar dos fundamentos literários, as Terceiras Estórias (Tutaméia) representariam a reflexão metalinguística sobre o acontecimento literário e as "segundas estórias" constituiriam a amostragem/leitura/fruição de toda a obra do autor.

As hipóteses são, em regra, fundamentadas por indicações de JGR, presentes e analisadas em seus textos. Rubens Alves Pereira, em seu ensaio “Segundas estórias e outros enigmas”, publicado em 2002, traz instrumentos do gênero fantástico, vinculado à literatura de mistério aos moldes de Edgard Allan Poe. Deste escritor, o estudioso observa a presença de traços de composição na obra Roseana, como exemplo, de "O Corvo" em "Sorôco, sua mãe, sua filha”, integrante de Primeiras Estórias; e mais: da narrativa policial de Poe, como "A carta furtada", na produção de JGR e, em especial, em Tutaméia. Na trilha de outros analistas da produção roseana, Pereira convoca Tutaméia - Terceiras Estórias para esclarecer as "segundas estórias" e conclui:

Pelo pouco que me foi intuído mostrar nesse rápido percurso pelas estradas, que
cruzam e se bifurcam, de Guimarães Rosa e de Edgard Allan Poe, chegamos à
plausível conclusão de que Tutaméia, com seu não-lugar expressamente
delimitado entre as Primeiras e Terceiras estórias, acaba por facultar, no seu
tempo vazio ("nonada") e na sua órbita seminal ("anedotas de abstração"),
complexas dimensões figurativas, as quais, provavelmente por princípio e por
força motriz, poderemos chamar de Segundas estórias. (PEREIRA, 2001, p. 264)

Em meu entender, no interior das Primeiras Estórias, encontram-se veredas que apontam direcionamentos às Segundas Estórias. O conto "Pirlimpsiquice", ao tratar, na aparência, sobre o contexto da educação juvenil - a estória narra eventos de um internato masculino -, não deixa também de ser um debate sobre o processo de criação, seus emaranhados e expectativas, e ainda da recepção crítica do produto: “Aquilo na noite do nosso teatrinho foi de Oh. O estilo espavorido. Ao que sei, que se saiba, ninguém soube sozinho direito o que houve. Ainda, hoje adiante, anos, a 
gente se lembra: mas, mais do repente que da desordem, e menos da desordem do que do rumor" (ROSA, 1968, p.39). Parte da crítica roseana não esquece de tangenciar essa questão do processo criativo como tema de "Pirlimpsiquice", como ocorre nos dois estudiosos de Primeiras Estórias, a seguir resenhados.

Maria Luíza Ramos, em “Análise Estrutural de Primeiras Estórias”, publicado inicialmente em O Estado de S. Paulo, de 30 de novembro de 1968 no Suplemento Literário, observa que “(...) o narrador se manifesta com força de personagem, chegando a constituir o elemento central da estória, não sé pela participação na intriga - tal se verifica em "A terceira margem do rio" e "Pirlimpsiquice" - como também pelos conceitos que emite, impressões sobre problemas diversos, ou locubrações sobre os fenômenos da vida (...)” (RAMOS, 1991, p.515). Dácio Antônio de Castro, em Primeiras Estórias: roteiro de leitura, publicado em 1993, constata sobre "Pirlimpsiquice":

\begin{abstract}
(...) o Autor desenvolve um estudo sobre a psicologia infantil, enquanto faz um comentário metalinguístico sobre o processo de criação artística, especialmente aquela que assume um caráter mágico, gerada pelo improviso. Com a irreverência e a alegria próprias da idade, um grupo de rapazes descobre como a emoção de inventar pode traduzir, com maior fidelidade, suas necessidade e suas aspirações. (...) $\mathrm{O}$ conto não deixa também de render sua homenagem à célebre teoria aristotélica do teatro (e da poesia em geral) como mimésis, isto é, imitação recriadora. (CASTRO, 1993, p.33)
\end{abstract}

Na minha leitura, toda a ambiguidade da sequenciação das estórias (ao menos, as "primeiras" e as "segundas") é discutida em "Pirlimpsiquice", tudo marcadamente submetido a um jogo metafórico/simbólico. Existe um clima de imprecisão, de incerteza, durante todo o ensaio, com inclusões/exclusões, estando o próprio narrador contaminado, desde o início: "Éramos onze, digo, doze” (ROSA, 1968, p. 39). A permanência da versão ensaiada da peça é precária e desde o começo, objeto de um pacto do grupo dos alunos envolvidos, receosos de assédios da suposta plateia:

Aí, mais, teve-se dúvida. Se os outros alunos se embolassem, para à força quererem fazer a gente contar a estória do drama? Dois deles preocupavam-nos, fortes, dos maiores dos internos, não pegados para o teatrinho por malcomportados incorrigíveis! Tãozão e o Mão-na-Lata, centerfór do nosso time. E um, cá, teve a ideia. Precisávamos de imaginar, depressa, alguma outra estória, mais inventada, que íamos falsamente contar, embaindo os demais no engano. E, de Zé Boné, ficasse sempre perto um, tomando conta. (ROSA, 1968, p.40)

No texto citado, aparece parte do ideário do JGR sobre a criação, aliás, presente em vários momentos de Primeiras Estórias: a existência de um pacto, o embate com a censura/recepção, as incertezas da solidariedade.

A primeira versão da estória, a ensaiada com o Dr. Perdigão, no dia do ensaio geral, é duramente criticada pelo "padre Diretor”, que comenta, para os alunos/atores: “(...) nós estávamos 
certos, mas acertados demais, sem ataque de vida válida, sem a própria naturalidade pronta...

Despejou conosco, tontos de consternados" (ROSA, 1968, p.41).

Por outra, no dia da apresentação, o narrador da estória - o "ponto" - assume o papel de um dos alunos/atores, por impossibilidade de cumprir obrigação inadiável: "Estava na portaria o tio de Ataualpa-o pai do Ataualpa era deputado, estava à morte, no Rio de Janeiro. Ataualpa tinha de viajar, de trem, daqui a duas horas. E o teatro, o espetáculo?” (p.44).

Nesse momento, no enredo de "Pirlimpsiquice", aparecem duas figurações costumeiras em Primeiras Estórias, como em "As margens da alegria" e "Os cimos" - a primeira e a última estória do livro: o intermediário/coadjuvante - "o tio", e o paciente/protagonista - "o menino/sobrinho".

A relação entre essas duas figuras promove/possibilita a descoberta de um mundo novo e diferenciado para o "menino", que, se o surpreende, o liberta de conquistas sem esforço, como reflete, em "Pirlimpsiquice", o narrador / "o ponto": "O contentamento-o medo. O fraque? O povo. O-ali, quem meio escondido, me cutucando - o Alfeu! Quer um gole?... - do que ele tinha furtado: uma garrafa de genebra, da adega dos padres- falava que era para dar mais alma de coragem. Eu não quis. (...)” (p.45).

Em "Pirlimpsiquice", há inversão de papéis: "o ponto" - fora de cena, por trás da "caixa", torna-se, pelo afastamento de Ataualpa, um dos alunos/atores, o primeiro a entrar em cena, cuja fala inicial era a única que "o ponto" não sabia de cor, o que impõe a presença do improviso, que marca tanto o início - “(...) Tornei a não olhar, falei alto. Gritei, tremulei, tão então: - Viva a Virgem e viva a Pátria! - gritei. Ressoaram enormes aplausos.” (p.45) -, como o final do drama:

Então, querendo e não querendo, e não podendo, senti: que-só de um jeito. Só uma maneira de interromper, ó a maneira de sair-do fio, do rio, da roda, do representar sem fim. Cheguei para a frente, falando sempre, para a beira da beirada. Ainda olhei, antes. Tremeluzi. Dei a cambalhota. De propósito, me despenquei. E caí. E, me parece, o mundo se acabou. (ROSA, 1968, p.47)

Do acontecimento narrado, depreende-se que JGR mostra que o exercício continuado, numa aprendizagem treinada - somente como espectador - permite que o mero observador, "o ponto", consiga uma atuação apropriada, inclusive, com a aceitação/aplauso do público/receptor.

No drama "Os Filhos do Doutor Famoso", há sugestões temáticas de uma genealogia artística. O decorrer da estória, disso se interessa: as diferentes versões/textos de uma só apresentação possível. O texto inicial e dos treinos diários dos alunos/atores, objeto das controvérsias, é retirado de cena na estreia. O que se mostra são outras versões: a de Gamboa (do grupo de alunos não atores) e a dos alunos/atores. 
Posso tomar, analogamente com as "primeiras" e as "segundas" estórias os movimentos/versões do "drama" apresentados em "Pirlimpsiquice"? Seriam as "primeiras" estórias a discussão de procedimentos/preparos da criação, enquanto as "segundas", as formas contextualmente possíveis/realizáveis?

Em sua estrutura de encadeamento, Primeiras Estórias é um livro de vinte e um contos, cindido ao meio por "O Espelho", ficando dez estórias em cada parte. O conto central funciona como uma espécie de filtro, através ou a partir do qual os temas da parte inicial são retrabalhados na segunda, sem qualquer correspondência linear, salvo o inicial cuja tema - a infância/a construção do saber - é retomado no último.

Em "O Espelho", como em "Pirlimpsiquice", o foco do relato está centrado na primeira pessoa, apresenta o narrador-protagonista que conduz a ação. Nessa estória, JGR dialoga com Machado de Assis, com o seu conto homônimo, e segue-lhe algumas trilhas. Apesar de construir um conto em terceira pessoa, Machado entrega a palavra ao casmurro Jacobina, que usa de artifícios também seguidos por Rosa: o monólogo/diálogo com interlocutores calados ou quase. No caso machadiano, quatro intradiegéticos, no caso roseano, um extradiegético. E mais: em ambas as narrativas, o público ouve, o narrador discorre sobre experiência personalíssima.

Escreve Machado: “(...) Mas, se querem ouvir-me calados, posso contar-lhes um caso da minha vida, em que ressalta a mais clara demonstração acerca da matéria de que se trata. Em primeiro lugar, não há uma só alma, há duas...” (ASSIS, 1997, p.346)

(Re)escreve Rosa: “- Se quer seguir-me, narro-lhe; não uma aventura, mas experiência, a que me induziram, alternadamente, séries de raciocínios e intuições.”(ROSA, 1968, p.71). As peripécias, machadiana e roseana, com o espelho desembocam no mesmo rio, em três tempos. Em três margens? Em três estórias? Porventura JGR explicitaria uma preocupação já implícita em MA?

Os embates dos dois escritores com o jogo de aparências, com o espelho, mostram-se em três instantes diferenciados: o primeiro, de projeção de uma imagem usual, corriqueira; o segundo, da não projeção da imagem usual, do desvio das aparências; o terceiro, o da volta/reconquista da imagem, da imagem renovada.

JGR (e não só ele, MA por igual) coloca no meio do caminho o espelho, como um pórtico de passagem necessária em busca da apreensão/fruição das experiências vividas. Não estaria esta estória servindo de âncora/chave/ponte para o entendimento do não-lugar das "segundas", das "primeiras" e das “terceiras" estórias?

Ambos os escritores parecem deixar para os receptores - por retirada (MA) ou por convite (JGR) - as respostas almejadas/solicitadas. Escreve Machado: "Quando os outros voltaram a si,o narrador tinha descido as escadas" (ASSIS, 1997, p.352). 
(Re)escreve Rosa: "Solicito os reparos que se digne dar-me, a mim, servo do senhor, recente amigo, mas companheiro no amor da ciência, de seus transviados acertos e de seus esbarros titubeados. Sim?” (ROSA, 1968, p.78). Parece-me que JGR entrega a seu receptor crítico a tarefa que lhe compete, como saboreia em "Famigerado", num duelo similar sobre os caminhos da significação da linguagem: “(...) tese para alto rir, e, no mais, o famoso assunto”.

\section{REFERÊNCIAS:}

ASSIS, Joaquim Maria Machado de. Obras Completas. Rio de Janeiro: Nova Aguilar, 1997.

CASTRO, Dácio Antônio de. Primeiras estórias: roteiro de leitura. São Paulo: Ática, 1993.

RAMOS, Maria Luíza. Análise estrutural de Primeiras Estórias. In: COUTINHO, Eduardo F. (Org.). Guimarães Rosa. 2. ed. Rio de Janeiro: Civilização Brasileira, 1991.

RÓNAI, Paulo. Os vastos espaços. In: ROSA, João Guimarães. Primeiras estórias. 4. ed. Rio de Janeiro: José Olympio, 1968.

ROSA, João Guimarães. Tutaméia: terceiras estórias. 2. ed. Rio de Janeiro: José Olympio, 1968.

ROSA, João Guimarães. Primeiras Estórias. 4. ed. Rio de Janeiro: José Olympio, 1968.

PEREIRA, Rubens Alves. Segundas estórias e outros enigmas. In: DUARTE, Lélia Parreira; ALVES, Maria Thereza Abelha (Org.). Outras margens: estudos da obra de Guimarães Rosa. Belo Horizonte: Autêntica: EdPUC, Minas, 2001.

PORTELLA, Eduardo. A Estória cont(r)a a História. In: COUTINHO, Eduardo (Org.) Guimarães Rosa. 2. ed. Rio de Janeiro: Civilização Brasileira, 1991. 